\title{
Family Planning Practices in Rural Community
}

\author{
Rosniza Aznie C. R. ${ }^{1}$, A. C. Er ${ }^{1}$, Abdul Rahim M. N. ${ }^{1}$, Lyndon N. ${ }^{1}$, Usman Y. ${ }^{2}$, Suriati G. ${ }^{2}$, Mohd Fuad M. J. ${ }^{1}$ \& \\ Mohd Yusof Hussain ${ }^{1}$ \\ ${ }^{1}$ School of Social, Development and Environmental Studies, Faculty of Social Sciences and Humanities, \\ Universiti Kebangsaan Malaysia, Malaysia \\ ${ }^{2}$ School of Humanities, Universiti Sains Malaysia, Malaysia \\ Correspondence: Rosniza Aznie C. R., School of Social, Development and Environmental Studies, Faculty of \\ Social Sciences and Humanities, Universiti Kebangsaan Malaysia, 43600 Bangi, Selangor, Malaysia. Tel: \\ 60-3-8921-5357, E-mail: aznie@ukm.my
}

Received: July 22, 2013 Accepted: September 1, 2013 Online Published: October 11, 2013

doi:10.5539/ass.v9n14p42 URL: http://dx.doi.org/10.5539/ass.v9n14p42

\begin{abstract}
This study focuses on the various factors that encourage the practice of family planning for rural communities in Malaysia. Family planning program is a modern alternative for married couples in determining the desired number of children in a family in addition to helping women obtain optimal health with birth intervals exist. It is associated in the field of demography which saw control of the birth rate of a family. Key reference data for this study are based on various population and housing census report Malaysia since the 1980s to 2010. This Followed by a field study based on the questionnaire on targeted population. Multivariate Analysis is used to cluster variables to key factors and then evaluated based on the significance of regression analysis as appropriate. The study found that the level of education, understanding husband, and type of work is the most significant factor influencing the practice of family planning. The study found that rural communities have begun to realize its importance but still not be able to receive a variety of modern methods of family planning practice to practice except oral contraceptives. Thus the results of the study provide some suggestions for improving the knowledge society towards good health and fertility potential trend towards the policy proposed by Malaysia's 70 million populations.
\end{abstract}

Keywords: community, rural, family planning, fertility, analysis

\section{Introduction}

In general, the practice of family planning is the determinant of unwanted pregnancies (Diana et al., 2005). Family Planning Practice (QIP) is defined as the act of making a decision to plan the right time to conceive through the use of various methods on grounds related to the space between births of children and to plan the size of children in the future (Jamsiah et al., 2009). Family planning was also found to reduce morbility and mortality (Amy \& Andreea, 2009; CDC Report, 2012; Advocates for youth, 2012; Stover \& John, 2010) among mothers and working to improve the quality of life better and comfortable with a well-balanced family size as planned (Merchant et al., 2006). The trends in fertility in women is said to have been influence by the family planning program, not because of the factor of easy accessibility of health services. In that case it is proved that family planning can reduce fertility of women who are still active to conceive.

For example, the effect of family planning programs occur in Ethiopia has succeeded in reducing the number of children born to women between the age of less than 20 years and older than 30 years. The women group, aged around 40 years to 45 years who are still able to have children is said to have a high fertility rate and they should undertake family planning to control the birth rate (Claus et al., 2011; Guttmacher Institute, 2010). Encouragement and government incentives also lead to acceptance of family planning practices in a country (Bryant \& Kellie, 2009; Zheng et al., 2012; Elfstrom, 2012). Women in Tennessee in 1975 and 1978 using family planning practices in place of birth control as abortion to avoid unwanted pregnancies among teenagers, aged about 20 years (Hani et al., 1970).Further, studies in Indonesia by Gustavo (2003) identify that with programs dealing with health and family planning can increase the level of women's ideas about the methods that can be used in the planning of family size. This is because the use of family planning practices can influence other activities such as low fertility and control the health of women where now there are issues of dangerous 
infectious diseases such as AIDS and sexually transmitted diseases (John, 2008).

In general, the family planning program is related to the acceptance by the couples in determining the desired number of children in the family in the near future (Al-Sammak, 2012). It is associated in the field of demography which saw control of the birth rate of a family. Family planning can be defined as the responsibilities of the spouses in deciding to have children by deciding the right time to conceive through certain methods such as spacing between pregnancies and limiting the size of the children in the family. Through the practice of family planning, it can improve the quality of life of the family so that they can enjoy a more comfortable life and can reduce the morbidity and mortality of mothers and children (Jamsiah et al., 2009). In addition, family planning practices are also seen as a contraceptive or method of birth practices that involve higher levels of knowledge, attitudes, and responsible decision by each spouse to have the number of children required to enhance the welfare of families in terms of health and to contribute to economic and social development of a state (John Thursday, 2008).

\section{Data and Methods}

\subsection{Data Source}

The selection of the study area involved rural communities in Besut Terengganu based on the reliability of selection of random samples with reliability percentage of 95 percent $(73.50$ percent $)$ and the number of respondents obtained involving 172 respondents among the married women only. Two methods of interviews were used i.e. interview based on questionnaires or interview key respondents based on snow ball sampling. Further, data analysis techniques involving the processing of data acquired while in the field using statistical methods of computerized data using computer software Statistical Package for Social Sciences (SPSS) to produce clean data from this study. The used of SPSS produced descriptive statistical analysis of the results involving the mean and standard deviation. In addition, the findings indicated from SPSS data analysis techniques and comparison also shows the relationship of the two variables in the study through the results of Pearson Correlation test analysis and AnovaSehala.

\section{Results}

On the whole the majority of respondents and spouse is aware of the practice of family planning to obtain the highest value of 78 per cent compared with the rest which still do not know and are not sure about any method of contraception.

\subsection{Choice of Family Planning Practices}

Determination and selection of the best time to have children is very important to improve the quality and ensure the quality of birth and health of the mother, particularly when the mother's health is at an alarming level and do not allow to give birth again. Most of the respondents $(n=46)$ is indeed practicing family planning to form a family size of their choice to control the number of children in the family and child spacing. Although the respondents are among the rural population, but a high level of knowledge about family planning methods has led them to join the run to avoid unplanned pregnancies. The respondents also consent and strong support from her husband to allow them to continue to practice until now. Moreover, the women involvement in the working world also encouraged them to change behavior in the formation of family because they fear of not fully committed to the development of their children. In fact some of them practice family planning because of certain reasons and mainly involve increasing age would cause them to reduce the reproductive period and the desire for a large family in the future.

\subsection{Family Planning Practice after Birth}

It is found, the respondents $(\mathrm{n}=46)$ have begun to adopt family planning after their first birth. The family planning is practiced from the after birth from their experience from the beginning after the first birth to the eight births. The findings of the descriptive analysis in Table 1 shows the average values of family planning practices after birth and the second birth in at the minimum of 2:07.Therefore there is a significant difference for family planning in the order of birth as the standard deviation is 1:39. The lowest amount shown for respondents who practice family planning after the birth of the second $(n=34)$, third $(n=18)$, fourth $(n=2)$, fifth $(n=2)$, sixth ( $=4)$ and seventh $(n=2)$. The use of family planning were more dominant after the first birth may be because of breastfeeding in the first long period cause respondents to take a longer time to get pregnant again in a second birth. Greater emphasis will be given to the first birth because at that time married couple is said to be excited to have their first child and it was the first experience by the couple after getting married. In addition, some couples decided to practice family planning to ensure that the first child is mature enough and then followed by the next birth. Strong financial position also plays an important role for regulation of family size after the first birth 
because there are still husband and wife who are less knowledgeable to consider the financial position as a result of the rising cost of living.

Table 1. Contraceptives Use after Birth Experiences

\begin{tabular}{lllll}
\hline Items & Minimum & Maksimum & Min & STD \\
\hline Contraceptive Use & 1.00 & 7.00 & 2.07 & 1.39 \\
\hline Source: Field Work (SPSS), 2012 & & &
\end{tabular}

Source: Field Work (SPSS), 2012

\subsection{Respondents, Reasons to Adopt Family Planning}

There are several reasons that cause the respondent to practice family planning. The most dominant factor is maternal factors $(\mathrm{n}=56)$. Maternal factor is indeed an obstacle to the desire to increase the number of children in the family. Such a case is that some of the young mothers are starting to suffer from life-threatening diseases caused by poor diet factors and it may affect the content if they intent to have more children. Examples are high blood pressure, diabetes, uterine problems, and miscarriages. If left unchecked, this will endanger the safety of the mother. The method of family planning in Malaysia is based on non-coercion policy so that the health of children and pregnant women are more secure (Tahir, 2006).

The second factor is the wish of child spacing if the number of children is too many, they are categorized as belonging to the "easy pregnancy" $(n=53)$. There are various methods for spacing the child birth, through the use of family planning practices such as breastfeeding method which take a long period of time and known as the Lactational Amenorrhea Method (LAM).This method is the natural method of family planning which would take a period of six months between births, breastfeeding is more common and is done before the arrival of the menstrual period (Kennedy et al., 1988). Therefore, family planning can indeed space-out between birth (Hasnilawati \& Hanafiah, 2006).

Involvement of respondents in employment and hold the family responsibility is one of the reasons to practice family planning among the respondents $(n=36)$. Respondents felt that they had to practice family planning in order to manage work and family. According to Fatima (1985), women have a problem to run two roles at the same time and at that time, conflicting roles can occur and responsibility of the child care are neglected. Such a case causes the respondent to make a decision to reduce the workload and make a full commitment to the management of children who need more attention to the practice of family planning

In addition, through family planning as well, a couple can have a more ideal family size according to their ability $(n=7)$. According Jamsiah (2009), the use of a modern method of contraception for those who have a high level of education and exposure to the urban environment have at least the ideal number of children of around five people. Such a case shows that the use of family planning practices capable to form the desired family size.

\subsection{Types of Family Planning Practices Used}

Family planning can be done in various ways either through devices, drugs or surgical procedures. With this method, a couple can enjoy sexual life without having to worry about pregnancy (Metro Maternity Hospital Bulletin, 2012).Based on the findings among respondents who practice family planning, among the known contraceptions and often used consists of two methods, which are modern and traditional methods. Mehods of family planning consist of the diet pills, the devices in the womb, injection, condoms, female surgery, keep sex, a traditional method and other related methods. The most dominant method adopted by the respondents is that the oral contraceptives $(27 \%)$ and the most rejected method is by means of surgery $(55 \%)$.Among the advantages for respondents who take oral contraceptives is because it is more readily available at any health center or pharmacy. Contraceptive pills are safe, effective and acceptable to most women who want longer child birth spacing. In fact, it consists of several types of pills which contain the hormones estrogen and progesterone pills such as Combine Oral Contraceptives (COCs), Progestin Oral Contraceptives (POCs) and Progestrerone Only Pills (POP). Examples are Marvelon, Nordette, Mercilon, Loette, Noriday and Yasmin (LPPKN, 2010). In fact, the percentage of successful application is practically 99 percent.

For the other contraception types used are such as a tool in the womb, by injection, condoms, female surgery, by keeping away from sex, a traditional method and other methods, are found the majority of respondents did not agree that they use all these methods to prevent pregnancy from occurring. Only a handful of respondents who use the method for family planning. Such a case because it causes a relatively high risk and impact in terms of 
health and safety for use in a long period of time.

\section{Discussions}

Practice of family planning is a decision-making method to determine the desired number of children for the future. Implementation of this practice can be done through a variety of treatment methods either traditional or modern. Both of these methods also have side effects from its use and personal preferences. Therefore, family planning is said to have a close relationship with a woman's fertility level. As such the number of family planning practices increases among career women that cause the declining fertility trends in a country. If seen, the older community practice less family planning because of the lack of exposure to contraceptive methods and under the circumstances would encourage a high birth rate as a result of no specific plan to control family size. On the other hand, advances in medical technology in Malaysia have prompted mothers with careers to use various methods of contraception for spacing purposes. Normally, before the marriage occurs, couples who wish to marry rarely think about the size of the family and planning to have children. In fact, some of them are not aware of the importance of family planning. Family planning is not only a method to limit the number of children, but it is a method that still encourage women to have more number of children up to five people, as long as each pregnancy has a special plan according to the needs and abilities of the partners. The practice of family planning is intended to widen the space between previous birth and the next birth. Birth spacing among children could lead to emotional disturbances among children because of lack of attention and affection more from the parents.

Through statistical analysis of the Pearson correlation between the actual number of children the ideal number of children (Table 2), there is a weak positive relationship between the actual number of children and number of children ideal and there is a significant difference, the value of the correlation coefficient is $.278 * *, p$ $<0.05$.Thus, for respondents who have many children, they consider ideal number of children is also true of the number of children they have. For example, the highest actual number of children is one of three to four people. While the number of children considered ideal by the respondents is more than the actual number of children between four and six people. For families who like to have many children, they assume the amount is balanced because they did not have any child care problems vice versa.

Table 2. Correlation Pearson analysis between actual number of and the ideal number of children

\begin{tabular}{|c|c|c|c|c|}
\hline & & $\begin{array}{l}\text { Actual } \\
\text { Children }\end{array}$ & Number of & $\begin{array}{l}\text { Ideal Number } \\
\text { Childrenl }\end{array}$ \\
\hline \multirow{3}{*}{$\begin{array}{l}\text { Actual } \\
\text { Children }\end{array}$} & Pearson Correlation & 1 & & $.278^{* *}$ \\
\hline & Sig. (2-tailed) & & & .007 \\
\hline & $\mathrm{N}$ & 170 & & 172 \\
\hline \multirow[t]{3}{*}{ Ideal Number of Children } & Pearson Correlation & $.278 * *$ & & 1 \\
\hline & Sig. (2-tailed) & .007 & & \\
\hline & $\mathrm{N}$ & 170 & & 172 \\
\hline
\end{tabular}

**Significant Correlation on 0.01 (2 way)

Source: Field Work (SPSS), 2012

The practice of family planning should be done taking into account of the determination of the desired number of children and age range of the children. If a woman who has just become pregnant again after giving birth before, their health will be affected. It is so because they can not take a long time to add back nutrients in their body, especially after having their first child.

Such a situation is caused by a problem of no special plans to keep the space distance for each child delivery. For example, the space between pregnancies are at least 18 months after birth (Samson, 2010).

Table 3 shows the results of statistical analysis Pearson correlation between the type of delivery with the ideal number of children born. The findings of the analysis found that there is a weak positive relationship between birth type and ideal number of children for the correlation coefficient close to 0 , where the value is .264* Perason correlation with $\mathrm{p}<0.05$.This means that there is a significant difference between the two variables, namely the more frequent practice of family planning done on every birth, more ideal the number of children that can be created in a family. Thus, the practice of family planning normally started in the first birth because they 
are still the first lactation and breastfeeding method is to some extent acting to distant the birth of the next child. Therefore, it can guarantee the health of mothers in need of rest and great care in terms of nutrition and continuous inspection.

Table 3. Correlation Pearson analysis type of birth and the ideal number of children

\begin{tabular}{llll}
\hline & & Type of Birth & Ideal Number of Children \\
\hline Type of Birth & Pearson Correlation & 1 & $.264^{*}$ \\
& Sig. (2-tailed) & & .038 \\
& $\mathrm{~N}$ & 168 & 168 \\
Ideal Number of Children & Pearson Correlation & $.164^{*}$ & 1 \\
& Sig. (2-tailed) & .038 & \\
& $\mathrm{~N}$ & 168 & 171 \\
\hline
\end{tabular}

**Significant Correlation on 0.05 (2 way)

Source: Field Work (SPSS), 2012

Table 4. Correlation Pearson analysis between education and the ideal number of children

\begin{tabular}{llll}
\hline & & Education & Ideal Number of Children \\
\hline Education & Pearson Correlation & 1 & .032 \\
& Sig. (2-tailed) & & .790 \\
& $\mathrm{~N}$ & 172 & 172 \\
Ideal Number of Children & Pearson Correlation & .0232 & 1 \\
& Sig. (2-tailed) & .790 & \\
& $\mathrm{~N}$ & 172 & 172 \\
\hline
\end{tabular}

Source: Field Work (SPSS), 2012

Level of knowledge about family planning practices is very important no matter whether for couples who wish to marry or are already married. However, there is still a married couple who misunderstood the actual meaning of family planning. There are some who consider that this practice is done for the purpose of limiting the number of children and there some who consider it is wrong from their religion point of view while family planning is associated with a planned pregnancy in terms of distance between the first pregnancy and subsequent pregnancies that is a specific plan for the child to be born especially for working mothers. Table 5 shows the results of statistical analysis Pearson correlation between respondents' level of knowledge of family planning practices (APK) with an ideal number of children. The findings of the analysis found that a weak negative relationship between the level of knowledge (APK) with the ideal number of children. Pearson correlation value is -.098 and there is no significant difference for $\mathrm{p}<0.05$. This means, the higher the level of knowledge about family planning practices among the respondents, the more likely to develop the ideal number of children in the family. Among the family planning methods that can be used to prevent pregnancy such as the oral contraceptives, condom usage, installation of the uterus, menstrual cycle count, injection and so on.

Tablel 5. Correlation Pearson analysis between contraceptive use knowledge and the ideal number of children

\begin{tabular}{llll}
\hline & & Contraceptive Use Knowledge & Ideal Number of Children \\
\hline Contraceptive Use Knowledge & Pearson Correlation & 1 & -.098 \\
& Sig. (2-tailed) & & .412 \\
& $\mathrm{~N}$ & 172 & 172 \\
Ideal Number of Children & Pearson Correlation & -.098 & 1 \\
& Sig. (2-tailed) & .412 & \\
& $\mathrm{~N}$ & 172 & 172 \\
\hline
\end{tabular}

Source: Field Work (SPSS), 2012 
Therefore, family planning is also a method used to prevent pregnancy. The results also showed that family planning use of traditional methods and modern methods. Based on this study, married couples who want to plan their families should know in advance about the type of family planning practices in the market that are safe, effective and easy to use without any unwanted side effects. They should consult a doctor to determine the most appropriate use of methods and can be suitable for them because there is some method of family planning noted to be ineffective and create a variety of side effects to health. For the traditional method, it covers the rules of the conventional method which is the old method such as anzal, breastfeeding for a long term, eating roots and herbs while also natural methods such as the period cycle. The modern methods are known by respondents involve mechanical methods such as condom use and the contraceptive devices of the uterus and permanent method of sterilization. Some respondents abstain from sexual intercourse with their partner as a way to prevent pregnancy. All use of family planning practices is dependent on the suitability of the couple because each has its own effectiveness and failure. For women who want many children and a large family, they are not interested in practicing family planning because they are still more comfortable with the existing number of children and the level of health that allows them to give birth again. In fact, there are those who do not practice family planning due to the absence of children.

Whereas the factor some respondents do not practice family planning is shown associated with the restrictions contained in the Islamic law literally, even though Islam does not forbid its followers to control family size because it depends on the ability of married couples to manage the children well in large number. For example, in Islam, Prophet Muhammad encourages marriage and childbirth. This is because the child is a gift that has no value. For some respondents who do not practice family planning methods due to the prohibition of the husbands, it also recorded the percentage of respondents who disagree and strongly disagree are the highest, respectively, by 11.6 percent. The percentage of Not Sure is the smallest percentage of respondents recorded 3.5 percent. Thus, the prohibition by husband factor is not a barrier to family planning. Such case is due to the decision to limit the size of the family involved a joint decision between husband and wife. Thus, the respondents do not face problems in terms of their opposition to the husband as the couple who really understand the needs of the family and the desire for a larger family size. In fact, it is probably not due to the resistance factors of the husband, while the respondent herself does not want to practice (Ahmad Fakaruddin et.al. 1995).

\section{Acknowledgement}

Appreciations are dedicated to Prof Dr Abdul Rahim Md Nor as a Project Leader for Research National Identity, Nationality, Cultural Diversity and Globalization, School of Social Development and Environmental Studies, Faculty of Social Science and Humanities and Research Grant UKM-GGPM-PLW-145-2010. At the same I would like to thank Associate Professor Dr Er Ah Choy under her grant UKM-DLP-2012-030 for giving seed money to me in publishing this article.

\section{References}

Abdullah, F. (1985). Wanita dan Pekerjaan: Satu Analisis Konflik Peranan (In Malay). Akademia, 27, 77-93.

Abdullah, H. (1989). Penduduk Semenanjung Malaysia: Struktur, Proses dan Masalah. Bangi: Universiti Kebangsaan Malaysia.

Advocates for youth. (2012). Adolescent Maternal Mortality: An Overlooked Crisis. Retrieved from http://www.advocatesforyouth.org/component/content/article/436-adolescent-maternal-mortality-an-overloo ked-crisis cited on 22/11/2012

Ahmad Fakaruddin, A. S., Azidah, A. K., Goh, W. C., Harmy, M. Y., Hasliza, M. S., IntanHakimah, I., ... Suresh, K. (1995). Kajian Mengenai Kelahiran Rapat dan Faktor-faktor yang Berkaitan dengannya di kalangan Ibu-Ibu di Kampung Kunci Air Buang, MukimTanjungKarang (In Malay). Malaysian Jurnal of Community Health, 2(2).

Ahmed Almualm, Y. K. (2008, July). Knowledge, Attitude and Practise of Husbands towards Modern Family Planning In Mukalla. Yemen. The Malaysian Journal of Medical Sciences, 15(3), 76-77.

Al-Sammak, N. I., Al-Jawadi, A. A. (2012). Contraceptive Use Dynamics among Married Women Attending Primary Health Care Centers in Mosul City, Iraq: A Cross-Sectional Study. Middle East Journal of Family Medicine, 10, 29-34.

Angeles, G., Guilkey, D. K., \& Mroz, T. A. (2003). The Effects of Education and Family Planning Programs on Fertility in Indonesia (In Malay). North Carolina: Measure Evaluation Project, University of North Carolina. 
Bryant, K. D. (2009). Contraceptive Use and Attitudes among Female College Students. ABNF Journal, 20, 12-16.

CDC Report. (2012). Sexual Experience and Contraceptive Use Among Female Teens-United States, 1995, 2002, and 2006-2010. Morbidity and Mortality Weekly Report (MMWR), 61(17), 297-301. Retrieved November 22, 2012, from http://www.cdc.gov/mmwr/preview/mmwrhtml/mm6117a1.htm

Che Rose, R. A., \& Ahmad, A. (2010). Peningkatan Pendidikan Menjejaskan Fertiliti Penduduk Tempatan: Konfirmasi dari Pembangunan BesutBaru, Terengganu. Bangi (In Malay). Geografia Online Malaysian Jurnal of Society and Space, 6(2), 51-62.

Cochrane, S. (1979). Fertility and Education: What do really know? Baltimore: John Hopkins University Press. World Bank Staff Occational Papers, No.26 Baltimore.

Diana, M., Bensyl, A., Iuliano, D., Marion, C., John, S., \& Brenda, C. G. (2005). Contraceptive Use - United States and Territories, Behavioral Risk Factor Surveillance System, 2002.November 18, 2005/54(S S06

Elfstrom, K. M., \& Stephenson, R. (2012). The Role of Place in Shaping Contraceptive Use among Women in Africa. Plos ONE, 7, 1-11,

Guttmacher Institute. (2010). Benefits of Meeting the Contraceptive. Needs of Ethiopian Women. Retrieved November 22, 2012, from http:/www.guttmacher.org/pubs/IB-Contraceptive-Needs-Ethiopia.pdf

Hani, K., Atrash, M. D., Rodger, W., Rochat, M. D., Kenneth, F., Schulz, M. B.A., ... Allen, M. D. (1970). Family Planning and Abortion: Have They Effected Fertility in Tennessee? Public Health Briefs, 20, 42-56.

Jamsiah. M., Rahmah, M. A., ShEzat, W. P., \& Shamsul, A. S. (2009). Amalan Perancangan Keluarga dan Faktor Hubung kait bagi Penduduk Wanita Daerah Hulu Langat, Selangor (In Malay). Jurnal of Community Health, 15(1), 57-63.

Kementerian Kewangan Malaysia. (1984). Laporan Ekonomi 1984/1985 (In Malay). Kuala Lumpur. Retrieved May 30, 2012, from http://www.pmr.penerangan.gov.my

Kennedy, K., Rivera, R., \& McNeilly, A. (1988). Consensus Statement: Breasfeeding as a Family. Planning Method, 1204-1205.

Lembaga Penduduk dan Pembangunan Keluarga Negara Malaysia (LPPKN). (2012). Perancangan Keluarga (In Malay). Kuala Lumpur. Retrieved May 30, 2012, from http://www.lppkn.gov.my

Merchant, R. C., Damergis, J. A., Gee, E. M., Bock, B. C., Becker, B. M., \& Clark, M. A. (2006). Contraceptive usage, knowledge and correlates of usage among female emergency department patients. Contraception, 74(3), 201-207. http://dx.doi.org/10.1016/j.contraception.2006.03.012

Metromaternity. (2012). Laporan Hospital Metro maternity (In Malay). Retrieved November 22, 2012, from http://www.metromaternity.com

Mohamad, H., \& Salleh, H. M. (2006). Factors Influencing Family Planning Practise Among Husbands In The District Of Marang Terengganu 1996. Jurnal Kesihatan Masyarakat, 12(1), 1675-1663.

Mustafa, J., \& Salleh, H. M. (1994). Perancang Keluarga di kalanganWanita Orang Asli di Daerah Hulu Langat.Selangor (In Malay). Jurnal of Community Health, 12, 1-20.

Omar, K. (2010). Kaedah Perancangan Keluarga (In Malay). Selangor: Pusat Rawatan Impian Medicare Sdn. Bhd. Retrieved May 30, 2012, from http://www.primedicare.com

Ping, L. Y. (1995). Fertiliti di kalangan Kaum Cina: Kesan Pembangunan Sosio ekonomi terhadap Pola Demografi (In Malay). Kuala Lumpur: Universiti Malaya.

Portner, C. C., Beegle, K., \& Christiensen, L. (2011). Family Planning and Fertility: Estimating Program Effects using Cross-Sectional Data. Washington: University of Washington. World Bank Policy Research Working Paper: 5812.

Razak, R. A. (2006). Fourth Malaysia Population and Family Survey (MPFS 4). In National Population Conference "Building the Next Generation". Kuala Lumpur.

Singawah, S. (2010). Health and Medicine: Pilihan Selamat bagi Perancangan Keluarga (In Malay). Retrieved June 14, 2012, from http://www.scribd.com/doc/29912333/Pilihan-Selamat-bagi-Perancangan-Keluarga

Stover, J., \& Ross, J. (2010, September). How Increased Contraceptive Use has Reduced Maternal Mortality. SOURCE. Maternal \& Child Health Journal, 14(5), 687. Retrieved April 18, 2012, from 
http://connection.ebscohost.com/c/articles/52946047/how-increased-contraceptive-use-has-reduced-materna 1-mortality

Tsui, A. O., \& Creanga, A. A. (2009). Does Contraceptive Use Reduce Neonatal and Infant Mortality? Findings from a Multi-Country Analysis. Retrieved from http://paa2009.princeton.edu/papers/91181. cited on $22 / 11 / 2012$

Yaakob, U. H. (1989). Prinsip Kajian Kependudukan (In Malay). Kuala Lumpur: Dewan Bahasa dan Pustaka.

Zheng, X., Tan, L., Ren, Q., Cui, Z., Wu, J., Lin, T., ... Chen, H. (2012). Trends in contraceptive patterns and behaviors during a period of fertility transition in China: 1988-2006. Contraception, 86(3), $204-213$. http://dx.doi.org/10.1016/j.contraception.2011.12.006

\section{Copyrights}

Copyright for this article is retained by the author(s), with first publication rights granted to the journal.

This is an open-access article distributed under the terms and conditions of the Creative Commons Attribution license (http://creativecommons.org/licenses/by/3.0/). 